FACTA UNIVERSITATIS

Series: Physical Education and Sport, Vol. 18, No 1, 2020, pp. 239 - 247

https://doi.org/10.22190/FUPES190630021C

Research article

\title{
PHYSICAL ACTIVITY AS ONE OF THE MOST OPTIMAL WAYS OF ACTIVE FATIGUE ELIMINATION AND OVERCOMING MIDLIFE CRISIS
}

\author{
UDC 796:615.63
}

\author{
Milica Čolović ${ }^{1}$, Aleksandar Gadžić ${ }^{1}$, Radovan Ilić ${ }^{1}$, Marko Petrović ${ }^{2}$ \\ ${ }^{1}$ Faculty of Physical Education and Sports Management, University Singidunum, \\ Belgrade, Serbia \\ ${ }^{2}$ Faculty of Law and Business Studies dr Lazar Vrkatić, Belgrade, Serbia
}

\begin{abstract}
The main aim of this research is to investigate the relationship between the characteristic ways of overcoming the midlife crisis and the various ways of fatigue elimination. More precisely, to examine the correlation between denial by escape, denial by overcompensation, decompensation, and creative and successful coping with the crisis on the one hand and fatigue elimination with chemical stimulants, with psychological stimulation and with physical activity (PA) and active rest on the other, as well as the gender differences within these variables. The sample consisted of 300 middle-aged people, aged between 40 and 64, uniform by gender. The following instruments were used: A list of the respondents' basic biodata, the Midlife Crisis Scale and an evaluation scale representing the basic techniques of fatigue elimination in participants from different categories specifically designed for the research. Since the score distribution on the tested variables statistically deviate from normal distribution, non-parametric techniques were used. Pearson's correlation coefficient was applied for determining the connection between variables and the Mann Whitney $U$ test for testing the difference between the groups of participants. The obtained results show that there is a statistically significant correlation between adequate PA, as a way of fatigue elimination, and the creative and successful coping with the crisis, as well as a moderate connection between different types of passive rest and decompensation, especially in women. It can be concluded that moderate, well-prescribed, and age-appropriate PA, as an important form of active rest, is connected with the most optimal way of coping with a midlife crisis.
\end{abstract}

Key words: Midlife Crisis, Adults, Physical Activity, Passive Rest, Fatigue

Received June 30, 2019/ Accepted April 13, 2020

Corresponding author: Aleksandar Gadžić

Faculty of Physical Education and Sports Management, University Singidunum, Danijelova 32, 11000 Belgrade, Serbia Phone: + 381113094094 •E-mail: agadzic@ singidunum.ac.rs 


\section{INTRODUCTION}

Until recently, psychology has unjustly ignored an important and long period in the life and development of each individual, which is a period of maturity (Pavlović, 2014; Čolović, 2017).

Earlier, it was considered that the most important developmental changes occur during the first five years of life, that in the latency period few psychological and biological changes take place, and that puberty and adolescence are the last "psychologically important and interesting" periods of revival of previous, as well as new changes in the emotional, biological and social aspects (Milošević \& Čolović, 2019).

The remainder of one's life was regarded as a relatively quiet period; however, with the work of eminent scholars and researchers and a more adequate perception of the everyday abilities, opportunities, needs and capacities of middle age people, it became clear that this period of life is certainly important and extremely rich in developmental changes. The current study points out and highlights the importance of physical activity (PA) as one of the adaptive and functional ways to adequately overcoming the normal developmental midlife crisis.

Increasingly, employed people can notice typical signs of fatigue, that manifest in the form of feeling exhaustion, lethargy, apathy, or irritability and mood swings (Čukić, 2003). Many of these psychological manifestations of fatigue are becoming an everyday routine for a large number of people and therefore represent a potentially serious problem for an individual and for their families, for which they do not have patience, energy and time. The appearance of fatigue is related to all, and therefore very different, human activities. In order to overcome fatigue, which in most cases transforms into a chronic condition, people in contemporary society employ very different strategies and ways of eliminating fatigue, some of which may be very dangerous for both physical and mental health.

PA and sports are considered as a completely natural and healthy way of eliminating fatigue, which, apart from the basic goal - fatigue elimination, will improve other spheres of human health and somatic and mental functioning (Chen, Chen, Martínez, Etnier, \& Cheng, 2019).

All three of these dimensions can be classified into mechanisms of successful and creative overcoming of the midlife crisis in physically active individuals. The person is fully aware that he/she has used the first half of their life, does not fall into a depression and does not despair (which is characteristic of decompensation), does not even deny the process of aging and what is happening to him/her (which is characteristic of mechanisms of denial with escape and overcompensation). Such a person in spite of the awareness of age and death, finds new sources of satisfaction and the meaning of life, taking care that, by practicing and working on himself/herself increases the quality of their life (Vuori, 2005; Pavlović, 2014; Čolović 2017).

The main aim of this research is to investigate the relationship between the characteristic way of overcoming of a midlife crisis and the various ways of fatigue elimination. In order to do that, the correlation between denial by escape, denial by overcompensation, decompensation, and creative and successful coping with the crisis one the one hand and the fatigue elimination with chemical stimulants, with psychological stimulation and with a PA and the active rest on the other are examined, as well as the gender differences within these variables. 


\section{METHODS}

\section{The sample of participants}

The study sample consisted of 300 middle-aged respondents, aged between 40 and 64 years, equally represented by gender. The sample was divided into two groups. The first group were those who daily (regularly) engage in some form of PA, while the second group were those who engage in some form of PA on an irregular basis (PA was not a part of their daily routine).

\section{Measures}

The following instruments were used: List of Basic Information on the Respondent, Midlife Crisis Scale-MCS (Pavlović, 2014), and an evaluation scale representing the basic techniques of fatigue elimination in respondents from different categories specifically designed for the research.

\section{Data Analysis}

Since the score distribution of the tested variables statistically deviates from the normal one, non-parametric techniques were used. To process the data, specific procedures for determining the normality of distribution of all variables in the scores of the respondents, Pearson's correlation coefficients for determining the correlation between variables and various procedures for testing the Mann-Whitney $U$ test were used to determine the differences between males and females. The statistical analysis of the data was performed using the SPSS program for data analysis in social sciences.

\section{RESULTS}

In the following tables (Table 1 and Table 2) the results of the normality of distribution test of the respondents' scores are shown. It can be seen that the distribution of scores on all of the examined variables statistically significantly deviates from the normal one, while the magnitude of the given deviation is represented by the value of Kolmogorov-Smirnov test.

Table 1 Kolmogorov-Smirnov test for variables that indicate coping mechanisms of midlife crisis

\begin{tabular}{ccccccccc}
\hline & \multicolumn{2}{c}{ Creative dealing } & \multicolumn{2}{c}{ Decompensation } & \multicolumn{2}{c}{ Denial with escape } & \multicolumn{2}{c}{ Denial with overcompensation } \\
\cline { 2 - 9 } & Statistic & Sig. & Statistic & Sig. & Statistic & Sig. & Statistic & Sig. \\
\hline Score & 0.074 & .000 & 0.067 & .000 & 0.045 & .000 & 0.035 & .000 \\
\hline
\end{tabular}

Table 2 Kolmogorov-Smirnov test for variables that indicates different ways of fatigue elimination

\begin{tabular}{ccccccccc}
\hline & \multicolumn{3}{c}{ Chemical stimulants } & Psychological stimulations & \multicolumn{2}{c}{ Physical activity } & \multicolumn{2}{c}{ Passive rest } \\
\cline { 2 - 9 } & Statistic & Sig. & Statistic & Sig. & Statistic & Sig. & Statistic & Sig. \\
\hline Score & 0.098 & .000 & 0.054 & .000 & 0.079 & .000 & 0.067 & .000 \\
\hline
\end{tabular}


Since the results of the Kolmogorov-Smirnov test for the distribution of scores in all of the examined variables showed that they do not have a normal distribution, nonparametric techniques were used in order to test the differences between genders.

The next step in the data analysis was to test the relationship between the two sets of variables, different types of midlife crisis coping mechanisms and different fatigue elimination techniques by means of Pearson's correlation coefficient.

Table 3 Relationship between different types of midlife crisis coping mechanisms and different fatigue elimination techniques

\begin{tabular}{|c|c|c|c|c|c|}
\hline \multirow[b]{2}{*}{$\begin{array}{l}\text { Coping mechanisms } \\
\text { Of the midlife crisis }\end{array}$} & & \multicolumn{4}{|c|}{ Different ways of the fatigue elimination } \\
\hline & & $\begin{array}{l}\text { Chemical } \\
\text { stimulants }\end{array}$ & $\begin{array}{c}\text { Psychological } \\
\text { stimulations }\end{array}$ & $\begin{array}{l}\text { Physical } \\
\text { activity }\end{array}$ & $\begin{array}{c}\text { Passive } \\
\text { rest }\end{array}$ \\
\hline \multirow{3}{*}{$\begin{array}{l}\text { Creative and successful } \\
\text { coping with }\end{array}$} & rho & .598 & & $.832^{* *}$ & \\
\hline & Sig. & .556 & & .000 & \\
\hline & $\mathrm{N}$ & 300 & 300 & 300 & 300 \\
\hline \multirow{3}{*}{ Decompensation } & rho & & & & $.537^{* *}$ \\
\hline & Sig. & & & & .000 \\
\hline & $\mathrm{N}$ & 300 & 300 & 300 & 300 \\
\hline \multirow{3}{*}{ Denial with escape } & rho & & & & \\
\hline & Sig. & & & & \\
\hline & $\mathrm{N}$ & 300 & 300 & 300 & 300 \\
\hline \multirow{3}{*}{$\begin{array}{l}\text { Denial with } \\
\text { overcompensation }\end{array}$} & rho & & & & \\
\hline & Sig. & & & & \\
\hline & $\mathrm{N}$ & 300 & 300 & 300 & 300 \\
\hline
\end{tabular}

It can be seen that there is a very high correlation between PA and creative and successful coping with the crisis $(\mathrm{rho}=0.832 ; \mathrm{p}<0.001)$. That means that moderate, well-prescribed, and age-appropriate PA as an important form of active rest can help a person to deal with and overcome a midlife crisis in the most optimal way. It can, after a long day, invigorate and restore the body, giving it the necessary energy for new challenges and can contribute to the strengthening of confidence and feelings of self-worth among middle age persons.

It is also noticed that passive rest is statistically significantly connected with decompensation ( $r h o=0.537 ; \mathrm{p}<0.001$ ). This may mean that passive rest in the form of lying down and avoiding any PA only exacerbates depression, amplifies the onset of negative thoughts, intensifies the fear of death, and a person descends into increasing despair.

As for the differences in terms of gender, the results showed that the scores of men and women from all age groups differ when it comes to eliminating fatigue with chemical stimulants and eliminating fatigue with active rest, while the differences in the third and fourth variable elimination of fatigue with psychological stimulation and passive rest were not statistically significant (Table 4). 
Table 4 Statistical significance of obtained differences

\begin{tabular}{lcccc}
\hline & Chemical & Psychological & Physical & Passive \\
& stimulants & stimulations & activity & rest \\
\hline Mann-Whitney U Test & 23442.000 & 24387.000 & 21318.000 & 30023.000 \\
Sig. & .000 & .099 & .000 & .658 \\
\hline
\end{tabular}

Legend: Group variable-Gender

Further, the Man-Whitney U test ranks for different ways of fatigue elimination in different genders showed that women often resort to certain chemical stimulants to eliminate signs of fatigue, while men more often use different types of active rest - PA (Table 5).

Table 5 Mann-Whitney U test ranks for different ways of fatigue elimination in different genders

\begin{tabular}{lcccc}
\hline Different ways of fatigue elimination & Gender & $N$ & MR & $\sum \mathrm{R}$ \\
\hline \multirow{2}{*}{ Chemical stimulants } & $\mathrm{F}$ & 150 & 515.88 & 87878.00 \\
& $\mathrm{M}$ & 150 & 276.33 & 56142.00 \\
& Total & 300 & & \\
Psychological stimulations & $\mathrm{F}$ & 150 & 316.54 & 98962.00 \\
& $\mathrm{M}$ & 150 & 284.46 & 87737.00 \\
& Total & 300 & & \\
\hline \multirow{3}{*}{ Physical activity } & $\mathrm{F}$ & 150 & 386.99 & 61222.00 \\
& $\mathrm{M}$ & 150 & 542.78 & 91831.00 \\
& Total & 300 & & \\
\hline
\end{tabular}

As for the differences between men and women, when we take into account the possible ways of coping with and overcome a middle-age crisis, the only statistically significant difference was observed for the variables of decompensation (Table 6).

Table 6 Statistical significance of the obtained differences

\begin{tabular}{lcccc}
\hline & $\begin{array}{c}\text { Creative } \\
\text { coping }\end{array}$ & Decompensation & $\begin{array}{c}\text { Denial } \\
\text { with escape }\end{array}$ & $\begin{array}{c}\text { Denial with } \\
\text { overcompensation }\end{array}$ \\
\hline Mann-Whitney U Test & 23442.000 & 24387.000 & 21318.000 & 30023.000 \\
Sig. & .359 & .000 & .486 & .558 \\
\hline \multicolumn{4}{c}{ Legend: Group variable-Gender }
\end{tabular}

Man-Whitney U test ranks for Basic manifestation of midlife crisis in different gender revealed that women expressed more decompensation than men.

Midlife is not necessarily a negative period in life for most people, but it does normally involve serious challenges which evoke changes in adaptive strategies. Women $(M R=576.54)$ are more likely than men $(M R=284.87)$ to, at the first hint of the crisis, react with a depressive mood, loss of interest in various things in life, increased concern about visible changes in their physical appearance and the fear of aging (Table 7). 
Table 7 Mann-Whitney U test ranks for Basic manifestation of midlife crisis in different genders

\begin{tabular}{lcccc}
\hline Basic manifestation of the midlife crisis & Gender & $N$ & MR & $\sum \mathrm{R}$ \\
\hline \multirow{3}{*}{ Creative coping with a crisis through physical activity } & $\mathrm{F}$ & 150 & 324.66 & 71992.00 \\
& $\mathrm{M}$ & 150 & 358.43 & 83108.00 \\
& Total & 300 & & \\
\hline \multirow{3}{*}{ Decompensation } & $\mathrm{F}$ & 150 & 576.54 & 98962.00 \\
& $\mathrm{M}$ & 150 & 284.87 & 87737.00 \\
& Total & 300 & & \\
\hline \multirow{2}{*}{ Denial with escape } & $\mathrm{F}$ & 150 & 435.98 & 88168.00 \\
& $\mathrm{M}$ & 150 & 399.01 & 98831.00 \\
& Total & 300 & & \\
\hline \multirow{3}{*}{ Denial with overcompensation } & $\mathrm{F}$ & 150 & 356.31 & 87898.00 \\
& $\mathrm{M}$ & 150 & 359.32 & 92827.00 \\
& Total & 300 & & \\
\hline
\end{tabular}

\section{DISCUSSION}

There is no person in any modern society that did not experience one of the typical signs of fatigue: some form of exhaustion, lethargy, apathy, or irritability and mood swings (Schaffner, 2016). People in contemporary society try very different strategies and ways to eliminate fatigue, which in most cases transforms into a chronic condition, and some of these strategies may be very dangerous for both one's physical and mental health (Loades \& Chalder, 2020). Fatigue can be eliminated in different ways. Some of them are quite healthy, natural and recommended (resting, psychological motivation), while others may have adverse effects (use of different types of hazardous chemicals - psychostimulants). Usually, there are three major groups of fatigue elimination strategies: Elimination of fatigue by chemical stimulants, Elimination of fatigue by psychological stimulation - motivation, and Elimination of fatigue by resting (active and passive rest).

By observing and summarizing all of these facts it can be said that active people of all ages have fewer health problems than those who usually sit. Playing sports or light PA, like walking and light exercise has a very positive impact on one's health, somatic as well as psychological (Calfas \& Taylor, 1994; Fox, 1999; Goran \& Treuth, 2001; Ströhle, 2009; Bherer, Erickson, \& Liu-Ambrose, 2013; Cvejić \& Ostojić, 2017; Mitraković et al., 2016), but also represents one of the most important and the best ways to rest, provides the fastest recovery of the tired body, enabling the energy to continue working (Kim, Kim, Newman, Ferris, \& Perrewé, 2019).

Considering the main aim of this research, the investigation of the relationship between the characteristic ways of overcoming a midlife crisis and the various ways of fatigue elimination, the results of Pearson's correlation coefficients indicated a very high correlation between PA and creative and successful coping with the crisis (rho=0.832; $\mathrm{p}<0.001$ ). These findings suggest that PA in middle-aged persons might be a positive associating factor to mental health outcomes, and are congruent with previous research on middle-aged women and men (Brown, Ford, Burton, Marshall, \& Dobson, 2005; Elavsky \& McAuley, 2007; Sörensen et al., 2008; Liu, Li, Li, \& Zhang, 2017). The significant correlation between passive rest and decompensation $(\mathrm{rho}=0.537 ; \mathrm{p}<0.001)$ is a clear indication that passive rest 
(or physical inactivity) exacerbates depression, amplifies the rumination of negative thoughts and a person's descent into increasing despair.

Further findings of the current study confirmed statistically significant differences between participants of different genders when it comes to the basic techniques of eliminating fatigue. Results indicate that women often resort to certain chemical stimulants to eliminate signs of fatigue, while men rather use different types of active rest - PA. In a view of the differences in the technique of the fatigue elimination with active rest by gender, they are consistent with findings from previous studies where it generally was found that men more frequently use active rest or PA than women (Frändin, Mellström, Sundh \& Grimby, 1995; DiPietro, 1996; Livingstone, Robson, McCarthy, \& Kiely, 2001; Rhodes, Janssen, Bredin, Warburton, \& Bauman, 2017).

If we consider a life crisis as a form of stress, it is a fact that there is a growing literature on the positive aspects of stress, sometimes called "the perceived benefits of stress" (Aldwin \& Sutton, 1998; Čolović, 2017). While coping may mitigate the effects of stress, being able to perceive and act upon it may result in positive long-term effects. These positive changes may include material gain, changes in perspective, stronger social bonds, increased coping skills, mastery and self-esteem, increased self-knowledge, and perhaps wisdom as well (Aldwin, 1994). This allows a person to be involved in many activities within the community, enjoy hobbies, find a new balance within themselves, and crown their life with new purpose and meaning, that is, in Marmor's terms, to creatively and successfully face a crisis (Pavlović \& Zlatanović, 2012).

\section{CONCLUSION}

The normal development of an individual, and therefore the aging process as its inevitable and integral component, cannot be stopped or prevented no matter how one seeks it and strives to achieve it. With age, our skin begins to lose elasticity, becomes loose, wrinkly, our hair becomes grey, women enter menopause. These physical changes on the face and body can pose serious narcissistic harm for persons who are in the middle and late period of life, especially in cultures that cherishes the cult of youth and beauty, as ours does.

Moderate, well-prescribed, age-appropriate PA is an important form of active rest, that after a long day invigorates and restores the body, giving it the necessary energy for new challenges, which can also alleviate the signs of aging and contribute to the strengthening of self-esteem and feelings of personal values in middle-aged persons. Such PA enables a person to become more active and to explore inner potentials and revive new or long forgotten interests.

Based on the results from the current study it can be concluded that PA in any form (from walking to the intense training and practicing certain sports) is an important basis of health, both physical as well as psychological.

\section{REFERENCES}

Aldwin, C. (1994). Stress, coping, and development: An integrative approach. New York: Guilford.

Aldwin, C.M., \& Sutton, K. (1998). A developmental perspective on post-traumatic growth. In R.G. Tedeschi, C.L. Park, \& L.G. Calhoun (Eds.), Posttraumatic growth: Positive change in the aftermath of crisis, (pp. 43-63). Mahwah, NJ: Lawrence Erlbaum Associates. 
Bherer, L., Erickson, K.I., \& Liu-Ambrose, T. (2013). A review of the effects of physical activity and exercise on cognitive and brain functions in older adults. Journal of Aging Research, https://doi.org/10.1155/2013/657508.

Brown, W., Ford, J., Burton, N., Marshall, A., \& Dobson, A. (2005). Prospective study of physical activity and depressive symptoms in middle-aged women. American Journal of Preventive Medicine, 29(4), 265-272.

Calfas, K.J., \& Taylor, W.C. (1994). Effects of physical activity on psychological variables in adolescents. Pediatric Exercise Science, 6(4), 406-423.

Chen, Y.C., Chen, C., Martínez, R.M., Etnier, J.L., \& Cheng, Y. (2019). Habitual physical activity mediates the acute exercise-induced modulation of anxiety-related amygdala functional connectivity. Scientific Reports, 9(1), 1-12.

Čolović, M. (2017). Kriza srednjih godina u savremenoj Srbiji (Midlife crisis in modern Serbia). Glasnik antropološkog društva Srbije, 52(1-2), 125-132. In Serbian

Cvejić, D., \& Ostojić, S. (2017). Effects of the fitt program on physical activity and health-related fitness in primary school age children. Facta Universitatis Series Physical Education and Sport, 15(3), 437-451.

DiPietro, L. (1996). Habitual physical activity among women. In O. Bar-Or, D.R. Lamb, \& P.M. Clarkson (Eds.), Perspectives in exercise science and sports medicine: Exercise and the female-a life span approach, (pp.740), Carmel, IN: Cooper Publishing Group.

Elavsky, S. \& McAuley, E. (2007). Physical activity and mental health outcomes during menopause: A randomized controlled trial. Annals of Behavioral Medicine. 33(2), 132-142.

Fox, K.R. (1999). The influence of physical activity on mental well-being. Public Health Nutrition, 2(3a), 411-418.

Frändin, K., Mellström, D., Sundh, V., \& Grimby, G. (1995). A life span perspective on patterns of physical activity and functional performance at the age of 76. Gerontology, 41(2), 109-120.

Goran, M.I., \& Treuth, M.S. (2001). Energy Expenditure, Physical Activity and Obesity in Children. Pediatric Clinics of North America, 48(4), 931-953.

Kim, M., Kim, A.C.H., Newman, J. I., Ferris, G.R., \& Perrewé, P.L. (2019). The antecedents and consequences of positive organizational behavior: The role of psychological capital for promoting employee well-being in sport organizations. Sport Management Review, 22(1), 108-125.

Liu, H., Li, F., Li, J., \& Zhang, Y. (2017). The relationships between urban parks, residents' physical activity, and mental health benefits: a case study from Beijing, China. Journal of Environmental Management, 190, 223-230.

Livingstone, M.B.E., Robson, P.J., McCarthy, S., \& Kiely, M. (2001). Physical activity patterns in a nationally representative sample of adults in Ireland, Public Health Nutrition, 4(5a), 1107-1116.

Loades, M.E., \& Chalder, T. (2020). Chronic fatigue in the context of pediatric physical and mental illness. In E. Taylor, F. Verhulst, J. Wong, K. Yoshida, \& A. Nikapota (Eds.), Mental health and illness of children and adolescents. Mental health and illness worldwide. Springer, Singapore.

Milošević, M., \& Čolović, M. (2019). Razvojna i pedagoška psihologija sa primenom u sportu i fizičkom vspitanju (Developmental and educational psychology with application in sports and physical education), Belgrade: Singidunum University, Faculty of Physical Education and Sports Management. In Serbian

Mitraković, D., Batez, M., Simić, M., Mikalački, M., \& Janković, M. (2016). The significance of physical activity of young schoolchildren. Facta Universitatis Series Physical Education and Sport, 14(3), 407-414.

Pavlović, M. (2014). Načini ispoljavanja krize srednjih godina, osećanje smisla života i oblici usklađivanja porodičnih i profesionalnih uloga $u$ Srbiji (Ways of expressing midlife crisis, sense of the meaning of life and forms of harmonization of family and professional roles in Serbia). Unpublished doctoral dissertation, Niš: University of Niš, Faculty of Philosophy. In Serbian

Pavlović, M., \& Zlatanović. Lj. (2012). Fizička aktivnost i kriza srednjih godina (Physical activity and midlife crisis). In N. Živanović, \& S. Bubanj (Eds.), Proceedings of the 15th Scientific Conference FIS Communication 2011 in Sport, Physical Education and Recreation, (pp. 178-185). Niš: University of Niš, Faculty of Sport and Physical Education. In Serbian

Rhodes, R.E., Janssen, I., Bredin, S.S., Warburton, D.E., \& Bauman, A. (2017). Physical activity: Health impact, prevalence, correlates and interventions. Psychology \& Health, 32(8), 942-975.

Sörensen, L., Pekkonen, M., Männikkö, K., Louhevaara, V., Smolander, J., \& Alén, M. (2008). Associations between work ability, health-related quality of life, physical activity and fitness among middle-aged men. Applied Ergonomics. 39(6), 786-791.

Schaffner, A.K. (2016). Exhaustion: a history. Columbia University Press.

Ströhle, A. (2009). Physical activity, exercise, depression and anxiety disorders. Journal of Neural Transmission, $116(6), 777-784$ 


\section{FIZIČKA AKTIVNOST I AKTIVNO ELIMINISANJE ZAMORA KAO JEDAN OD NAJOPTIMALNIJIH NAČINA PREVAZILAŽENJA KRIZE SREDNJIH GODINA}

Osnovni cilj ovog istraživanja bio je da se ispita povezanost između karakterističnih načina prevazilaženja krize srednjih godina i različitih načina otklanjanja umora. Preciznije, da se ispitaju korelacije između poricanja sa bekstvom, poricanja sa natkompenzacijom, dekompenzacijom $i$ kreativno suočavanje sa krizom sa jedne strane, i otklanjanja zamora hemijskim stimulatorima, psihološkom stimulacijom, putem fizičke aktivnosti i aktivnog odmora, kao i razlike po polu u okviru ovih pokazatelja. Uzorak ispitanika činilo je 300 ispitanika srednjih godina, između 40 i 64 godine ujednačen po polu. Primenjeni su sledeći instrumenti: Skala krize srednjih godina-SKSG i za potrebe ovog istraživanja konstruisana skala za procenu osnovnih tehnika za otklanjanje umora ispitanika različitih grupa. S obzirom da su pokazatelji ditribucije ukazali na statistički značajno odstupanje od normalne distribucije, primenjene su neparametrijske statističke procedure. Primenjen je Pirsonov koeficijent korelacije u cilju određivanja povezanosti između varijabli, a Mann Whitney U test za testiranje razlika između ispitivanih grupa. Dobijeni rezultati pokazali su da postoje statistički značajne korelacije između adekvatne fizičke aktivnosti kao načina za otklanjanje umora i kreativnog suočavanja sa krizom, kao i umerene korelacije između različitih oblika pasivnog odmora $i$ dekompenzacije, posebno kod žena. Može da se zaključi da je umerena, pravilno dozirana i uzrasno odgovarajuća fizička aktivnost kao važan oblik aktivnog odmora povezana sa sa najoptimalnijim načinom suočavanja sa krizom srednjih godina.

Ključne reči: kriza srednjih godina, odrasli, fizička aktivnost, pasivni odmor, zamor 